Figueiredo, J.P.; Pereira, L.M.; Schuwartz, G.M. Perfil dos turistas de aventura e ecoturistas de Brotas (SP): investigação da percepção de condutores. Anais do VIII Congresso Nacional de Ecoturismo e do IV Encontro Interdisciplinar de Ecoturismo em Unidades de Conservação. Revista Brasileira de Ecoturismo, São Paulo, v.4, n.4, 2011, p. 569.

\title{
PERFIL DOS TURISTAS DE AVENTURA E ECOTURISTAS DE BROTAS (SP): INVESTIGAÇÃO DA PERCEPÇÃO DE CONDUTORES
}

\author{
Juliana de Paula Figueiredo*, Leonardo Madeira Pereira*, Gisele Maria Schwartz* \\ Universidade Estadual Paulista Júlio de Mesquita Filho - Câmpus Rio Claro \\ E-mails: julianapfig@hotmail.com, lelmadeira@yahoo.com.br, schwartz@rc.unesp.br
}

O conhecimento sobre o perfil dos clientes é fundamental para a tomada de decisões estratégicas das empresas, no sentido de melhorar a qualidade e o direcionamento do atendimento, porém, este aspecto nem sempre é levado em consideração. Neste sentido, este estudo descritivo e comparativo teve por objetivos verificar a percepção que os condutores de turismo de aventura da cidade de Brotas/SP possuem a respeito do perfil dos turistas de aventura e ecoturistas, assim como, comparar esses resultados aos dados constantes no Perfil dos Turistas de Aventura e Ecoturistas no Brasil (ABETA, 2010). O instrumento utilizado para a coleta de dados foi referente a um questionário misto, aplicado a uma amostra intencional composta por 20 condutores de turismo de aventura da cidade de Brotas/SP. Os dados foram analisados descritivamente e expressos em porcentagens, evidenciando que $55 \%$ dos condutores desconhecem o documento da ABETA, realizado em parceria com o Ministério do Turismo, sobre o Perfil dos Ecoturistas e $45 \%$ têm conhecimento do mesmo. As modalidades em que os condutores pesquisados atuam são desenvolvidas na água (42\%) e na terra (58\%). Dentre as aquáticas, destaca-se, principalmente, o trabalho com o rafting e o bóia-cross, e entre as terrestres, o trekking, o arborismo, a escalada, a tirolesa, o rapel e treinamentos corporativos. Entre os condutores, $75 \%$ percebem que a maioria dos ecoturistas é do sexo masculino e $25 \%$ afirmam a predominância do sexo feminino. $68,2 \%$ dos condutores ressaltam que a faixa etária predominante é de 18 a 29 anos e $52,4 \%$ evidenciam que a situação familiar dos praticantes é principalmente a de casados com filhos, sendo a grande maioria oriunda do Estado de São Paulo, na visão de $95 \%$ dos condutores. Todos os condutores acreditam que os ecoturistas se deslocam para Brotas de carro e $52,6 \%$ percebem que estes estão geralmente acompanhados por cônjuges/namorados(as). Ainda, na visão de $81 \%$ dos condutores, esse público planeja em casa a viagem e, para $58,8 \%$, as atividades que serão realizadas na cidade são decididas no próprio local. $O$ envolvimento desse público com a atividade foi considerado por $95 \%$ dos condutores como de pessoas que praticaram de 01 a 10 diferentes tipos de atividades de aventura no Brasil. Os resultados deste estudo sobre a percepção dos condutores a respeito do perfil dos ecoturistas de Brotas, quando comparados com os do documento da ABETA sobre o Perfil Nacional, não apresenta muitas diferenças, ressaltando-se diferenças apenas no que tange à companhia para a viagem e à situação familiar, uma vez que os ecoturistas, no Perfil Nacional, preferem os amigos para acompanhá-los nas atividades e são predominantemente solteiros. Tendo em vista que grande parte dos condutores pesquisados não possui conhecimento sobre o perfil do ecoturista nacional, embora apresente uma percepção próxima à dos dados do Perfil Nacional, torna-se importante realizar um levantamento local com os ecoturistas, para subsidiar estratégias mais eficazes de intervenção na atuação, tanto dos condutores, quanto das empresas que divulgam e operam essas atividades.

Palavras-chave: Ecoturista; Turismo; Aventura. 